\title{
Impacts of Flood on Food Crop Production and the Adaptive Measures Among Farmers in the Northern Guinea Savanna of Agroecological Zone of Kaduna State, Nigeria
}

\author{
Adedapo James Olufemi, Awobona Temitope Ajibola, Ogunsanwo Julius Adeniyi, \\ Ijah Aiyedogbon Adoga, Bolaji Olusegun William, Emmanuel Jayeola Oladimeji, \\ Akanni John Rachael
}

Forestry Research Institute of Nigeria, Federal College of Forestry Mechanization, Afaka, Kaduna, Nigeria

Email address:

femiadedapo2014@gmail.com (A. J. Olufemi)

\section{To cite this article:}

Adedapo James Olufemi, Awobona Temitope Ajibola, Ogunsanwo Julius Adeniyi, Ijah Aiyedogbon Adoga, Bolaji Olusegun William, Emmanuel Jayeola Oladimeji, Akanni John Rachael. Impacts of Flood on Food Crop Production and the Adaptive Measures Among Farmers in the Northern Guinea Savanna of Agroecological Zone of Kaduna State, Nigeria. American Journal of Environmental Science and Engineering. Vol. 4, No. 3, 2020, pp. 42-48. doi: 10.11648/j.ajese.20200403.13

Received: August 13, 2020; Accepted: August 24, 2020; Published: September 3, 2020

\begin{abstract}
The analysis of the impact of flood on food crop production and the adaptive measures amongfarmers was carried out in northern guinea savanna of agroecological zone of Kaduna State. In order to achieve the set objectives, purposive sampling technique was employed in collecting data from 380 food crop farmers withstructured questionnaire. Data was analysed using descriptive statistics and Chi square. Results show that majority (73.1\%) of respondents were male, while $67 \%$ were between the age of $21-40$ years. The level of education of the respondents indicates that about (58\%) had at least primary school education. Majority of the respondents $(93 \%)$ were prone to flood, while $96 \%$ normally experience flood in at least every five years. The study also shows that, above 50\% of respondents were affected by loss of soil nutrients; erosion, damage to road and other infrastructures, food insecurity, and poverty, while $96 \%$ of the respondent agreed that planting of vegetation, proper drainage, prevention of soil erosion and building dams, water ways and canals were adopted by the farmers as adaptation and control measures. It was recommended that, the extension agents should disseminate information and also made available improved varieties of plant and animal species which the farmer could use in combating flood effects.
\end{abstract}

Keywords: Impact, Flooding, Adaptive Measures, Food Crop, Northern Guinea Savanna

\section{Introduction}

Flooding is when a dry area overflows with water and is not able to absorb it into the ground. The hazard of flooding is an annual phenomenon that has displaced millions every year worldwide and claimed lives and properties [1]. According to Bariweni and Etuonovbe, Nigeria experiences floods every year especially flash floods and dam related floods during the raining season [2, 3].

Flood hazards occur naturally, but the level of impact, damage and losses are as a result of human activities [4]. The threat to lives and property by flood is now becoming an annual event in many urban and rural areas in Nigeria [5]. Flood occurs when surface water covers land that is normally dry or when water overflows normal confinements. The most widespread of any hazard, floods can arise from abnormally high precipitation, storm surges from tropical storms, dam bursts, and rapid snow melts or even burst water mains. The majorities of floods are harmful to humans [3]; however, floods can provide benefits without creating disaster and are necessary to maintain most river ecosystems. Floods replenish soil fertility, provide water for crop irrigation and fisheries and contribute seasonal water supplies to support life in arid lands. Flooding is basically a natural phenomenon, which can be caused or even intensified in most cases by human activities. Flooding has been identified as one of the 
major factors that prevents Africa's growing population of city dwellers from escaping poverty and stands in the way of United Nations 2020 goal of achieving significant improvement in the lives of urban slum dwellers [4].

Flooding is a worldwide trend and should be treated with urgency as many regions are getting to a stage that is considered unfit for human survival due to land degradation. This has resulted in conflicts over extreme depletion of natural resources, increase in population and poverty causing severe risk to political, economic, and social stability [6]. Way before crude oil was discovered in commercial quantity in Nigeria, agriculture was the major trade and source of livelihood and economic growth. Agriculture is still rich in the country's growth and plays a vital role in economic growth so it has to be protected [7].

The declining agricultural productivity in Nigeria is worrisome and a real challenge for Government with a population of approximately 150 million people to feed. Climate change affects agriculture in several ways, one of which is its direct impact on food production. It brings additional perspective to the national challenge of increasing agricultural production to keep pace with the rising population while keeping high standards of environmental protection. Negative effects on agricultural yields will be exacerbated by more frequent extreme weather events [8]. Adaptation reduces the negative impact of climate change [9, 10]. Adaptation of agronomic techniques and farm strategies is already happening [8]. The modification of agricultural practices and production in order to cope with flooding will be imperative in order to meet and continue meeting the growing food demands of Nigerians. Evidence shows that farming systems and farming technologies within the region have been changing in response to the effects of flooding [11]. In their study conducted in Southwest Nigeria, Adebayo et al. showed that the farmers agreed that the main flooding effect is on reduction of their personal productivity [11]. Adapting to flood at the farm-level by the farmers especially through the modification of agricultural practices and farming systems has been recognized as the main coping strategies. It is believed that these strategies are supposed to help the farmers improve their personal productivity and efficiency in food crop production and also raise their returns to farming as a business. Previous studies conducted on efficiency (technical and profit) of farmers only used socioeconomic, farmers' and farm-specific characteristics to determine the efficiency level of their production [12-16].

The broad objective of this study is to analyze the effect of flood and adaptive measures on small land crop farmers in Chikun Local Government Area of Kaduna State, Nigeria. The specific objectives are to: (i). describe the socioeconomic characteristics of farmers in the study area; (ii). determine the flood rate in the study area; (iii). identify the impact of flood in the study area,(iv). investigate on the adaptation measures adopted by small land crop farmers in the study area.

\section{Purpose of the Study}

The present inability of food crop production sector to meet the foods demand of Nigerians and the challenge posed by floods emphasized the need for the improvement of food crop farmers. Failure to know the present food crop production efficiency (technical and profit) and the influence of flood coping strategies on efficiency level of food crop production will inhibit designing and formulating appropriate policies to meet food crop production demands of the country. Developing economies can benefit much from inefficiency studies especially a type like this that incorporates farmers' adaptation strategies to flood hazards to explain efficiencies. The results of this study are expected to give direction for policy makers in designing appropriate public policies to increase agricultural productivity and mitigating effects of flood on food crop production in Nigeria especially in the Northern zone. It will provide a useful guide to international and local donor agencies interested in flood mitigation and adaptation in their provision of grants and funds for environmental and resource management studies The results of this study will also help agricultural planners in the Agricultural Development Programmes (ADPs) and Ministries of Agriculture, Science and Technology; and Environment in the northern region and Nigeria as a whole and those states in the zone with Agroclimatological and Ecological zone study Units in their planning activities and providing useful weather data that will guide in planning public (or planned) adaptations to complement the farm-level (or autonomous) adaptation strategies. Researchers are going to have a good resource base to look at flood for further work. Farmers are also going to benefit by knowing those adaptation measures to flood that are more productive and efficiency-enhancing.

\section{Materials and Methods}

\subsection{Study Area}

The study was carried out in Chikun Local Government Area (LGA) of Kaduna State. Chikun LGA covers an area of about $445,659 \mathrm{~km}$ with a projected population of 502,500 people according to the 2016 census figure [17]. The jurisdiction of royal chief covers parts of Kaduna south local government area of television village village and Romi new extension. Chikun drives it name from Gbagyi village in the south eastern part of kujama. Chikun Local Government Area lies between the latitude and longitude $10^{\circ} \mathrm{N}$ and $8^{\circ} \mathrm{E}$ on the equator (See Figure 1). 


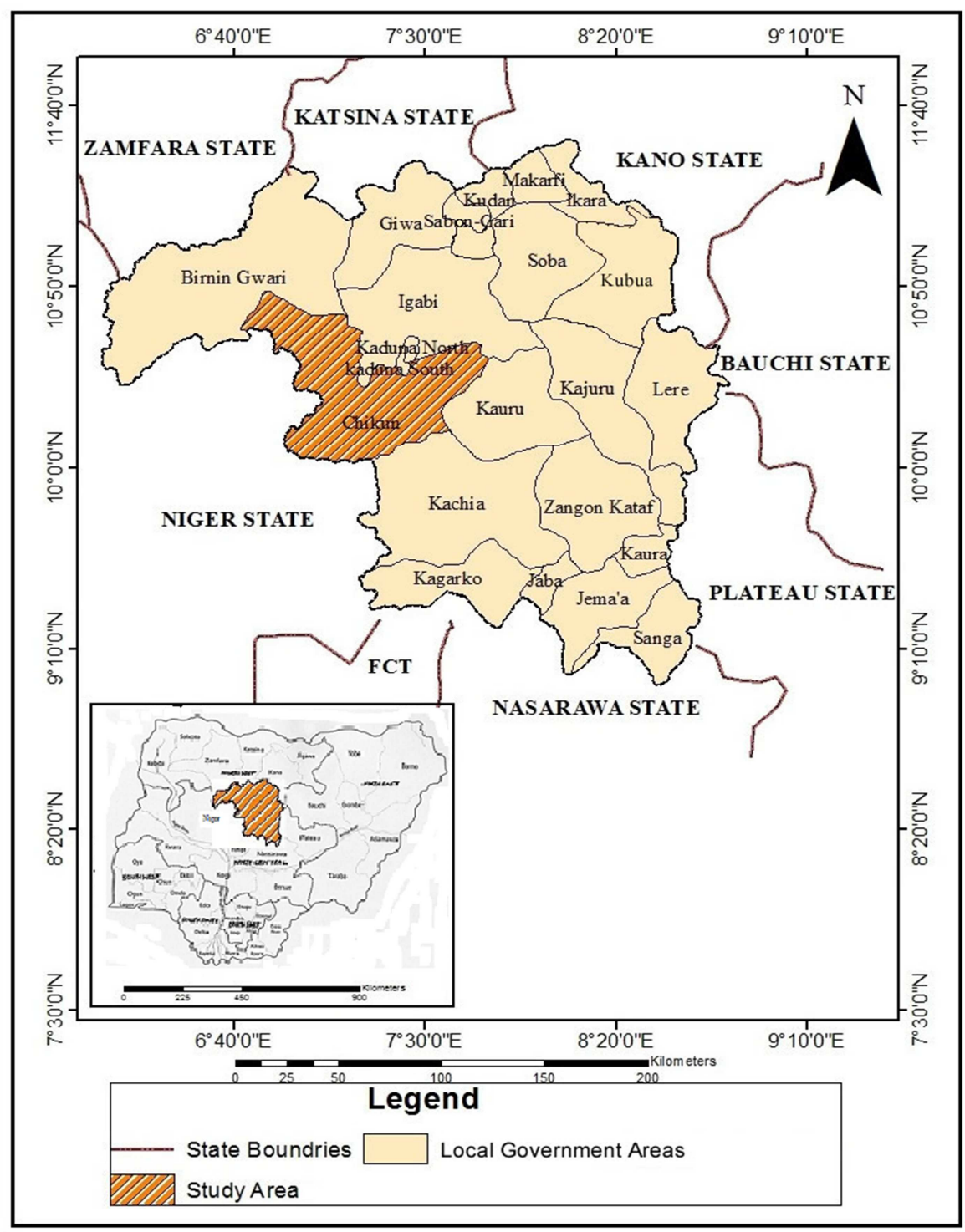

Figure 1. Map of Kaduna State and the Study Area.

Chikun LGA is situated in Northern Guinea Savanna Zone, and shares boundaries with Igabi and Kaduna South LGA to the Northand with Kajuru to the East, BirninGwari and Giwa LGA to the West and Kachia LGA to the South.

The ethnic group in the study area comprises of Gbagyi predominantly, Hausa, Kataf, Igbo, Fulani, Bwari, Idoma/Kulus and Yoruba constituted more than half of the population in the local government. Their main occupation is farming and they plant rice, yam, maize, guinea corn, millet and cassava, they also reared animals such as goat, sheep and cow, they practice traditional and modern agro-forestry system in the area and they are also civil servants and traders [18].

\subsection{Data Collection, Sampling Technique and Analytical Techniques}

In this study, primary data was collected from the respondents through the use of well-structured questionnaire which was administered to the respondents to achieve the set objectives. While the secondary data from text book, journal, website, unpublished materials and proceeding of conference etc.

Chikun LGA is made up of thirteen districts; eight (Ungwanromi, Kamazo, Nassarawa, kakau, Sabogayar, Kudenda, Gonin-gora and umgwanmaigero) of flood prone districts were purposively selected for the collection of data. Twenty respondents were randomly selected from each district which gives a total number of one hundred and sixty (160) respondents.

Both descriptive and inferential statistics were used to achieve the stated objectives. Descriptive statistics such as frequency table, percentage (\%) was used to achieve objective $\mathrm{i}$ and iii. While likert scale and chi square were used to establish the relationship between the flood impacts and the adaptation measures adopted by the farmers in the study area.

The Chi Square $\left(X^{2}\right)$ formula used is as follows: 


$$
X^{2}=\sum \frac{(O-E)^{2}}{E}
$$

Where $X^{2}=$ Chi Square, $\sum=$ Summation, $\mathrm{O}=$ Observed Frequency, $\mathrm{E}=$ Corresponding Expected Value.

\section{Result and Discussion}

\subsection{Socio-economic Characteristic of the Respondent}

Table 1: The tables below described the socio-economic characteristic of the respondent using the following induces: sex, Age, marital status, level of education, house hold size, religion, monthly income, membership in organization, source of capital, source of labour.

The study carried out showed that the majority $73.1 \%$ of the respondents are male while $26.9 \%$ of the respondents are females. This shows more participation of men in farming than women in the study area.

Below shows that the average age of the respondents was $32.77 \%$. While $21.2 \%$ of the respondents were in the age range of $21-30$ years. This was followed by $46.2 \%$ with the age range of $31-40$ years and $25.7 \%$ with age range of 41 $50 y e a r s$, while $8.98 \%$ and $3.1 \%$ were in the age range of 50 years and above. The age distribution of the respondents indicate that about $95 \%$ of the farmers in the study area were in their working age group which make them more active. Age is an important factor in any agricultural activity. According to Agbo, age is inversely related to performance [19].

Table 1 shows that $14.3 \%$ of the respondents were single, $65.7 \%$ of the respondents are married, $11.9 \%$ are divorced and $8.1 \%$ are widowed.

According to the results in the study area, a very large proportion of the farmers are married. The status of a married farmer is very important, as spouses contribute significantly in the study area.

Below shows about $77.3 \%$ of the respondents had one form of education or the other while about $22.7 \%$ of the respondents did not have any form of education. Farmers level of education is very important as it helps the farmer in adopting new ideas, strategies, knowledge to know how to tackle problems if it arises. The high number of their level of education can determine the rate of adoption of improved technique due to their knowledge of enlightenment and information through education. Okpukpura stated that education enhances level of understanding of saving; Nasiru stressed that attendance to formal education is aprerequiste for getting a secure or a regular employment which lead a more stable income from which marginal propensity of save increase $[20,21]$.

Table 1 shows that the household size with the highest frequency of $44.3 \%$ falls within the range of 6-10 persons. It shows that majority of the farmers had their household size within 6-10 persons. In view of the size of the household, agricultural activities are labour intensive and large household can provide family labour at least cost [22].
Table 1. Socio-Economic Characteristics of the respondents.

\begin{tabular}{|c|c|c|}
\hline Variable & Frequency & Percentage (\%) \\
\hline \multicolumn{3}{|l|}{ Gender } \\
\hline Male & 117 & 73.1 \\
\hline Female & 43 & 26.9 \\
\hline Total & 160 & 100 \\
\hline \multicolumn{3}{|l|}{ Age Group } \\
\hline Below 20 years & 6 & 3.8 \\
\hline $21-40$ Years & 108 & 67.4 \\
\hline $41-60$ Years & 41 & 25.7 \\
\hline Above 60 Years & 5 & 3.1 \\
\hline Total & 160 & 100 \\
\hline \multicolumn{3}{|l|}{ Marital Status } \\
\hline Single & 23 & 14.3 \\
\hline Married & 105 & 65.7 \\
\hline Widower & 13 & 8.1 \\
\hline Divorced & 19 & 11.9 \\
\hline Total & 160 & 100 \\
\hline \multicolumn{3}{|l|}{ Educational Level } \\
\hline Non Formal & 36 & 22.7 \\
\hline Arabic Education & 31 & 19.3 \\
\hline Primary & 31 & 19.3 \\
\hline Secondary & 48 & 30 \\
\hline Tertiary & 14 & 8.7 \\
\hline Total & 160 & 100 \\
\hline \multicolumn{3}{|l|}{ House Hold Size } \\
\hline $1-5$ & 45 & 28.1 \\
\hline 610 & 71 & 44.3 \\
\hline $11-15$ & 34 & 21.3 \\
\hline Above 15 & 10 & 6.3 \\
\hline Total & 160 & 100 \\
\hline \multicolumn{3}{|l|}{ Monthly Income } \\
\hline Less Than $\# 10,000$ & 7 & 4.3 \\
\hline$\# 11,000$ - \#20,000 & 15 & 9.3 \\
\hline$\# 21,000-\# 30,000$ & 20 & 12.6 \\
\hline$\# 31,000-\# 40,000$ & 40 & 25 \\
\hline$\# 41,000-\# 50,000$ & 75 & 46.9 \\
\hline Above $\# 50,000$ & 3 & 1.9 \\
\hline Total & 160 & 100 \\
\hline \multicolumn{3}{|l|}{ Labour } \\
\hline Family & 26 & 16.2 \\
\hline Hired & 48 & 30 \\
\hline Family and Hired & 41 & 25.7 \\
\hline Mechanical & 21 & 13.1 \\
\hline Animal Tractor & 24 & 15 \\
\hline Total & 160 & 100 \\
\hline
\end{tabular}

Source: Field Survey, 2019.

The table 1 also shows that $4.3 \%$ of the respondents earn a monthly income below 10,000 . It also shows that $9.3 \%$ of the respondents earn a monthly income between $11,000-20,000$, it also show that $12.6 \%$ of the respondent earn a monthly income between $21,000-30,000$, it also shows that $25 \%$ of the respondent earn a monthly income $31,000-40,000$, and also shows that $46.9 \%$ of the respondent earn a monthly income between $41,000-50,000$, while $1.9 \%$ of the respondent earn a monthly income of 51,000 and above

The result in table 1 shows that $30 \%$ of the respondents use hired labour, $16.2 \%$ used family labour, $13.1 \%$ use mechanical labour, $15 \%$ make use of animal labour, while $25.7 \%$ of the respondent go with family member and hired people on their farm land. 


\subsection{Examine the Flood Rate in the Study Area}

The result of the study showed the distribution of the respondents based on the flood rate, effect of flood and adaptive measures on small land crop farmers. The indices addressed include; experienced flood/ farm water logging, types of flood experienced on the farm, and the time taken the flood to drain from the farm land, proximity to the river stream in their farm, frequency of experiencing flood in their farm land.

The results of the study from figure 2 below shows that $93 \%$ of the farmers land are prune to flood, while $7 \%$ of the respondents have no disturbance of flood / farm water logging in their land.

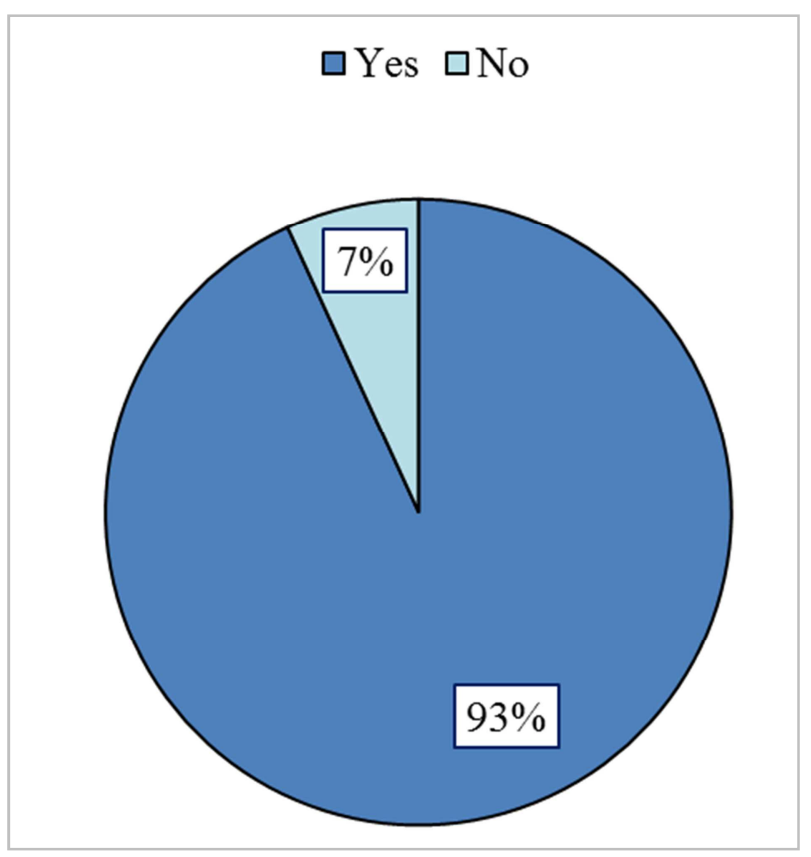

Figure 2. Respondents Experienced Flood.

\subsection{Identified the Impact of Flood in the Study Area}

The table 2 below shows the distribution of the respondents based on the impact of flood in the study area. The table shows that majority $(65 \%)$ of the respondent agreed that flood lead to erosion and damage of infrastructure respectively.(64.3\%) of the respondent agree that flood leads to bad road,(61.2\%)of the respondents agree that flood lead to food insecurity, $(57.5 \%)$ and $(56.2 \%)$ of the respondents agree that flood lead to livestock destruction and increase poverty respectively. (50.7\%) of the respondent agree that flood lead to loss of soil nutrient, $(46.2 \%)$ of the respondent agree that lead to loss of farmland, $(44.3 \%)$ of the respondent agree that flood lead to loss of properties while few $(33.1 \%)$ of the respondent agree that flood lead to loss of life. This result shows that majority of the respondent agree that flood lead to erosion and damage to infrastructure. This implies that flood leads to erosion in farmland where food crops and farmland are being wiped out, building submerged. This is in line with the finding of Premium Time [23]. While in the aspect of disagree, majority (66.9\%) of the respondent disagree that flood leads to loss of life, $(55.7 \%)$ and $(53.8 \%)$ the respondent disagree that flood leads to loss of properties and loss of farmland, (49.3\%) of then respondent shows that flood doesn't lead to loss of soil nutrient, $(43.8 \%)$ of the respondent shows that flood doesn't lead to livestock destruction.

Table 2. Distribution to determine the Impact of flood in the study area.

\begin{tabular}{llllll}
\hline \multirow{2}{*}{ Impacts } & Yes & \multicolumn{3}{c}{ No } & \multirow{2}{*}{ Total } \\
\cline { 2 - 5 } & Freq & \% & Freq & \% & \\
\hline Loss Of Lives & 53 & 33.1 & 107 & 66.9 & 160 \\
Loss of Properties & 71 & 44.3 & 89 & 55.7 & 160 \\
Loss of Farmland & 74 & 46.2 & 86 & 53.8 & 160 \\
Loss of Soil Nutrient & 81 & 50.7 & 79 & 49.3 & 160 \\
Caused Erosion & 104 & 65 & 56 & 35 & 160 \\
Lead to Bad Road & 103 & 64.3 & 57 & 35.7 & 160 \\
Damage to Infrastructure & 104 & 65 & 56 & 35 & 160 \\
Food Insecurity & 98 & 61.2 & 62 & 38.8 & 160 \\
Livestock Destruction & 90 & 56.2 & 70 & 43.8 & 160 \\
Increased Poverty & 92 & 57.5 & 68 & 42.5 & 160 \\
\hline
\end{tabular}

Source: Field Survey, 2019.

\subsection{Adaptation Measures Adopted by Small Land Crop Farmer}

The table 3 below shows the various adaptation measures adopted by small land crop farmers. The table according to likert scale revealed that all adaptation measures adopted by the respondents, are agreed to control and prevent all the impacts of flood in the study area.

Table 3. Adaptation measures adopted by small land crop farmers.

\begin{tabular}{lll}
\hline Adaptation Measures & Likert Scale & Remarks \\
\hline Planting vegetation & 2.96 & Agreed \\
Proper drainage & 2.96 & Agreed \\
Prevention of soil erosion & 2.94 & Agreed \\
Flood Control Programmes & 2.90 & Agreed \\
Proper Waste Disposal & 2.88 & Agreed \\
Building Dams, Water Ways and Canals & 2.85 & Agreed \\
Construction of building above flood level & 2.66 & Agreed \\
\hline
\end{tabular}

Source: Field survey, 2019.

\subsection{Hypothesis Testing}

Ho: there is no significant impact of flooding in the study area.

Among the impact of flooding the chi square analysis revealed that poor road network $\left(X^{2}=9.250, \mathrm{P}\right.$ value $\left.=0.01\right)$, cause of erosion $\left(X^{2=} 9.839, \mathrm{P}\right.$ value $\left.=.043\right),\left(X^{2}=10.009, \mathrm{P}\right.$ value $=.040)$, were significant to the impact of flooding, while other impact of flooding were not significant, Loss of life $\left(X^{2}=5.433\right.$. $\mathrm{P}$ value= 219$)$, Loss of properties $\left(X^{2}=2.519, \mathrm{P}\right.$ value $=.601)$ and $\left(X^{2}=2.901, \mathrm{P}\right.$ value $\left.=.593\right)$. Therefore the null hypothesis is here by rejected. This implies that poor road network, erosion, infrastructural damage have been perceived to bea great impact as a result of flood in the study area. 
Table 4. Chi-square analysis of respondent on Impact of flood in the study area.

\begin{tabular}{lllll}
\hline Variable & $\boldsymbol{X}^{\mathbf{2}}$ & DF & P - Value & Remark \\
\hline Loss Of Lives & 5.433 & 3 & 0.219 & NS \\
Loss of Properties & 2.519 & 1 & 0.601 & NS \\
Loss of Farmland & 2.901 & 3 & 0.593 & NS \\
Loss of Soil Nutrient & 2.900 & 2 & 0.563 & NS \\
Food Insecurity & 18.024 & 4 & 0.061 & NS \\
Lead to Bad Road & 9.250 & 6 & 0.001 & $\mathrm{~S}$ \\
Livestock Destruction & 17.839 & 5 & 0.160 & $\mathrm{NS}$ \\
Caused Erosion & 9.839 & 4 & 0.043 & $\mathrm{~S}$ \\
Damage to Infrastructure & 10.009 & 4 & 0.040 & $\mathrm{~S}$ \\
Increased Poverty & 1.818 & 4 & 0.769 & $\mathrm{NS}$ \\
\hline
\end{tabular}

Source: Field survey, 2019.

\section{Conclusion and Recommendations}

This study was carried out to analyze the effect of flood and adaptive measures on small land crop farmers in Chikun Local Government Area of Kaduna state located in northern guinea savanna of agroecological zone of Nigeria. The specific objectives were to: describe the socio-economic characteristics of farmers in the study area; determine the flood rate in the study area; identify the impact of flood in the study area; and investigate on the adaptation measures adopted by small land crop farmers in the study area.

The study concluded that the high level of education and majority of youth age bracketmake a very important factors that helped in the study area to formulate and adopt new ideas, strategies and proper knowledge and understanding to adapt, control and prevent flood from causing a great havoc like loss of life, property and farmland in the study area.

The result also shows more men participate in farming than women in the study area. Educated household heads chose livestock production as their major livelihood choices. Lastly the study suggested to the households to use cover cropping, i.e. planting vegetation, use of dams and canals, flood and erosion control measures, proper drainage and waste disposal strategy as a response to flooding. Weather forecasting, resistance varieties of plant/ animal species, education and skill upgrade, emergency relief strategies and forest regulations were not the strategies use by the surveyed respondents.

Based on the findings of this study, the following recommendations have been made:

(a) Government (State and local) should make more land available for crop production, since larger land sizes encouraged crop production as a major livelihood choice in the study area. This is because crop farmers could diversify their crops to spread the risk of loss associated with flood;

(c) Government in all tiers should make policies and strategic investment plans that will improve access to climate forecasting and information so that farmer will know the appropriate farm level adaptation technology to employ in combating flood and its impact; and

(d) Extension agents should disseminate information and also make available improved varieties of plant and animal species which the farmer could use in combating flood.

\section{References}

[1] Bronstert, A., 'Floods and Climate Change: Interactions and Impacts'. Risk Analysis, Vol. 23, No. 3. (2003).

[2] Bariweni, P. A., Tawari, C. C. and Abowei, J. F. N. Some Environmental Effects of Flooding in the Niger Delta Region of Nigeria. International Journal of Fisheries and Aquatic Sciences 1(1): 35-46, 2012 ISSN: 2049-8411; e-ISSN: 2049842X (C) Maxwell Scientific Organization, (2012).

[3] Etuonovbe, A. K., The Devastating Effect of Flooding in Nigeria. Hydrography and the Environment. Accessed online on the

8http://www.fig.net/pub/fig2011/papers/ts06j/ts06j_etuonovbe 5002.pdf (2011).

[4] Action Aid Climate change, urban flooding and the rights of the urban poor in Africa. A report by Action Aid International (2006).

[5] Olanrewaju D. O and Fadairo G Flooding as an Induced Environmental Problem. Journal of the Nigerian Institute of Town Planners (2003) XVI (1) 85-95.

[6] Schwartz P and Randall D. An Abrupt Climate Change Scenario and its Implication for United States National Security (2003).

[7] Bello, O. B., Ganiyu, O. T., Wahab, M. K. A., Afolabi, M. S., Oluleye, F., Ig S. A., Mahmud, J., Azeez, M. A. and Abdulmaliq, S. Y., 'Evidence of Climate Change Impacts on Agriculture and Food Security in Nigeria' International Journal of Agriculture and Forestry 2012, 2(2): 49-55 DOI: 10.5923/j.ijaf.20120202.08.

[8] Commission of the European Communities [CEC]. Adapting to climate change: challenges for the European agriculture and rural areas. Commission staff working document accompanying the white paper- Adapting to climate change: towards a European framework for action (2009).

[9] Adger, W. N.; Huq, S.; Brown, K.; Conway, D. \& Hulme M. Adaptation to Climate Change in the Developing World. Progress in Development Studies No. 3. (2003).

[10] Kurukulasuriya, P. \& Mendelsohn, R. A Ricardian analysis of the impact of climatemedium-scale soybean production in Benue State, Nigeria. African Journal of Research and Agriculture, (2006).

[11] Adebayo, K., Dauda, T. O., Rikko, L. S., George, F. O. A., Fashola, O. S., Atungwu, Emerging and indigenous technology for climate change adaptation in the farming systems of southwest Nigeria: Issues for policy action (ATPS Technobrief No. 27). Nairobi, Kenya: African Technology Policy Studies Network. (2011).

[12] Ajibefun, I. A. Linking Socio-economic and policy variables to technicalefficiency of traditional agricultural production: empirical evidence from Nigeria. Poster paper prepared for presentation at the International Association of Agricultural Economists Conference, Gold Coast, Australia. (2006, August 12-18).

[13] Ayoola, G. The world Bank Assisted Agricultural Development projects as model for public sector financing in Nigeria in: Essay on agricultural development policy and administration in Nigeria TMA publishers, Ibadan, Nigeria. (2001). 
[14] Ogundari, K. Determinants of profit efficiency among small scale rice farmers in Nigeria: a profit function approach. A Poster Paper Prepared for Presentation at the International Association of Agricultural Economists Conference, Gold Coast, Australia (2006, August 12-16).

[15] Otitoju, M. A. Determinants of technical efficiency in small and medium-scale soybean production in Benue State, Nigeria. Unpublished M. Sc dissertation submitted to the Dept. of Agricultural Economics, University of Nigeria, Nsukka. (2008).

[16] Otitoju, M. A. \&Arene, C. J.. Constraints and determinants of technical efficiency inmedium-scale soybean production in Benue State, Nigeria. African Journal of Agricultural Research, (2010) 5 (17), 2276-2280. Available online at http://www.academicjournals.org/AJAR.

[17] National Population Commission NPC: Censuses. Accessed online on the 3 rd of May 2015. (2016). http://www.population.gov.ng/index.php/censuses.

[18] Agwu, J., and Okhimamhe, A., 'Gender And Climate Change In Nigeria': A Study Of Four Communities In North-Central And South-Eastern Nigeria. ISBN: 978 - 978 - $904-502-0$. Copyright CHeinrich BöllStiftung (HBS), (2009).

[19] Agbo, F. U. Cooperatives as Vehicle for Agricultural Adaptation to Climate Change in Nigeria In: Enete, A. A. and
Uguru, M. I. (2012). Critical Issues in Agricultural Adaptation to Climate Change in Nigeria. A production of Faculty of Agriculture University of Nigeria, Nsukka (2012).

[20] Okpukpura, D. C. Determinant of choice of financial institution among rural savers: implication for a sustainable rural financial saving mobilization for agricultural development. In: $19^{\text {th }}$ Annual conference of farm management association of Nigeria (FAMAN) held at Delta State University Asaba, on $18^{\text {th }}-29^{\text {th }}$ (2005). 309-315.

[21] Nasiru, M., Haruna, U. Abdurahman, S. \& Dauda, M.. Economic analysis of fish marketing and distribution in Bauchi state. Proceeding of African farm management (AFMA) $7^{\text {th }}$ Biennial congress (2005) 349-357. Publishers daily graphic Nigeria.

[22] Ojemade, A. C., Edeh, H. O., and Onemolease, E. A. Socio economic factor influencing membership of oil palm farmers producers cooperative societies in Ethiope West Local Government Area of Delta State, Nigeria. Proceedings of the $42^{\text {nd }}$ Annual conference of Agricultural society of Nigeria. (2008) Pp 741-745.

[23] Premium Times Flood in Jimeta, Yola. Accessed online on the $18^{\text {th }}$ of June (2015) via

http://www.premiumtimesng.com/news/97908-adamawaflood17dead-50000-homeless.html. 